\title{
How to Treat Asymptomatic and Symptomatic Urinary Tract Infections in the Kidney Transplant Recipients?
}

\author{
Zafar Iqbal ${ }^{1,2}$, Juan Fernando Ortiz ${ }^{3}$, Sawleha Arshi Khan ${ }^{4}$, Amr Salem ${ }^{5}$, Nusrat Jahan ${ }^{6}$ \\ 1. Emergency Medicine, California Institute of Behavioral Neurosciences and Psychology, Fairfield, USA 2. Emergency \\ Department, The Kidney Center, Karachi, PAK 3. Neurology, California Institute of Behavioral Neurosciences and \\ Psychology, Fairfield, USA 4. Research, California Institute of Behavioral Neurosciences and Psychology, Fairfield, USA \\ 5. Hospital Medicine, California Institute of Behavioral Neurosciences and Psychology, Fairfield, USA 6. Internal \\ Medicine, California Institute of Behavioral Neurosciences and Psychology, Fairfield, USA
}

Corresponding author: Zafar Iqbal, drzafariqbalsmc@gmail.com

\begin{abstract}
Patients with end-stage renal functions are treated with renal transplantation. After the transplantation, kidney transplant recipients (KTR) are at the risk of urinary tract infection (UTI). UTI in KTR may be symptomatic and asymptomatic. Asymptomatic UTI is the presence of the organisms without any signs and symptoms. There are various ways suggested in the published research papers to deal with UTI in the KTR. The goal of this literature review is to explore how to treat symptomatic and asymptomatic UTI in KTR. A PubMed search was conducted to identify the studies explaining the methods used to deal with UTI in KTR. A total number of 2158 articles were found while searching for regular keywords; however, we found 996 articles with the medical subject heading (Mesh) keywords. After applying the inclusion/ exclusion criteria, 56 articles with the regular keywords search and 29 articles with the Mesh keywords search were selected. These articles included 24 randomized clinical trials, 16 clinical trials, 7 review articles, 5 case reports, 2 controlled clinical trials, 2 observational studies, and 1 cross-sectional study. Our analysis has shown that the early removal of the stent after the transplantation and the use of antibiotics are beneficial in reducing the incidence of symptomatic UTI in the KTR; whereas, treating asymptomatic UTI in KTR has not been proven helpful in reducing the incidence of developing symptomatic UTI later on.
\end{abstract}

Received 07/15/2020 Review began 07/19/2020 Review ended 07/22/2020 Published 08/07/2020

(c) Copyright 2020 lqbal et al. This is an open access article distributed under the terms of the Creative Commons Attribution License CC-BY 4.0., which permits unrestricted use, distribution, and reproduction in any medium, provided the original author and source are credited.
Categories: Urology, Nephrology

Keywords: urinary tract infection, kidney transplant recipients, urinary tract infection in kidney transplant recipients

\section{Introduction And Background}

The mortality rates in kidney transplant recipients (KTR) are approximately $8.6 \%$ within the five years of the transplantation. Among them, 53\% are secondary to an infection elsewhere in the body [1]. The incidence of urinary tract infection (UTI) in the renal transplant recipients accounts for $45-72 \%$ of all the infections. [2] In the KTR, 30\% of all hospitalizations are secondary to UTI [2]. The UTI can be asymptomatic and symptomatic. The asymptomatic UTI is defined as the presence of the organism; however, there are no signs and symptoms and it accounts for $17-51 \%$ of infections in the KTR and risking the individuals for the subsequent UTI [3].

Several articles have been published in the past that have shown the incidence of UTI in the KTR and various ways to prevent it from occurring. Whether to treat KTR suffering from asymptomatic UTI with the antimicrobials and the impacts of antimicrobials therapy or dealing with the urinary catheters in individuals with symptomatic UTI after the transplantation have been discussed in these articles $[4,5]$. The knowledge of dealing with the asymptomatic and the symptomatic UTI in the KTR is important in order to improve the health of these individuals, minimize the incidence of hospital admission, and reduce the financial burden on the health sector.

The aim of this literature review is to evaluate the available data in order to find the measures for the treatment of asymptomatic and symptomatic UTI in KTR.

\section{Review}

\section{Method}

The available literature was searched in PubMed with regular keywords and medical subject heading (MeSH) subheadings to collect data.

Regular keywords for literature search included urinary tract infection in kidney transplant recipients, urinary tract infections, and kidney transplant recipients. While searching for the regular keywords UTI in KTR, UTI, and KTR, a total number of 2158 articles were found. Out of them, 56 articles were selected for 


\section{Cureus}

this review.

The literature was also searched for MeSH keywords. MeSH keywords for literature search included UTI in KTR, UTI, and KTR. This search found 996 records and 29 of them were included in this study.

Studies were selected after applying the inclusion/exclusion criteria. Inclusion criteria involved studies on clinical trials, controlled clinical trials, randomized clinical trials, observational study, reviews, systemic reviews, human studies, papers published in the English language, and case reports. However, exclusion criteria involved studies meta-analysis, animal studies, and papers published in other than the English language.

\section{Results}

Table 1 shows the total number of articles found while searching for the regular keywords UTI in KTR, UTIs, and KTR. A record of 2158 articles was found, and after applying the inclusion/exclusion criteria, 56 articles were selected and reviewed.

$\begin{array}{ll}\text { Regular keywords: Urinary tract infection in kidney transplant recipients, urinary tract infection, kidney transplant recipients } \\ \text { Total records } & 2158 \\ \text { English } & 1895 \\ \text { Human } & 1682 \\ \text { Systematic reviews } & 315 \\ \text { Review } & 313 \\ \text { Observational study } & 109 \\ \text { Clinical trials } & 89 \\ \text { Controlled clinical trial } & 56 \\ \text { Randomized controlled trial } & 56\end{array}$

\section{TABLE 1: Total number of articles after applying inclusion/exclusion criteria}

Table 2 shows the total number of articles found while searching for the MeSH keywords UTI in KTR, UTIs, and KTR. This search found 996 articles. After applying the inclusion/exclusion criteria, 29 articles were selected and reviewed.

\begin{tabular}{ll|}
\hline MeSH keywords: Urinary tract infection in kidney transplant recipients, urinary tract infection, kidney transplant recipients \\
\hline Total records & 996 \\
English & 852 \\
Human & 847 \\
Systematic reviews & 146 \\
Review & 145 \\
Observational study & 55 \\
Clinical trials & 43 \\
Controlled clinical trial & 29 \\
Randomized controlled trial & 29
\end{tabular}

TABLE 2: Total number of articles after applying inclusion/exclusion criteria 
Overall, a total number of 85 articles were selected from the regular and MeSH keywords search UTI, UTI in KTR, KTR, and reviewed. Rests of the 3069 articles were removed due to one of the reasons not specifying the disease of interest, meta-analysis, animal studies, and the paper published in other than the English language. All the available records reviewed were free including the citations. A manual collection of data was done after reviewing individual articles and applying inclusion/exclusion criteria in order to include the relevant articles.

\section{Discussion}

In the analysis of the 57 published articles, we found out that the most common bacterial infection in KTR is UTI and the majority of the causative organisms found included Gram-negative (76\%) with Escherichia coli (33\%) and Enterococcus and Klebsiella enterobacter (20\%) [6]. The predisposing factors for the UTI in the KTR are indwelling catheters, anatomical defects, neurogenic bladder, rejection, traumatic injury to the renal system, and immunosuppressant [6]. Identification and treatment of the risk factors are crucial in order to reduce the incidence of UTI in the KTR. This analysis focused on the various ways adopted to deal with the number of asymptomatic and symptomatic UTI in KTR.

The presence of ureteric stents and catheters in the KTR predisposes them to UTI. Table 3 shows that the removal of these ureteric stents and catheters earlier can play a pivotal role in reducing the incidence of UTI in the KTR. On average, the removal of ureteric stents and catheters as early as one to two weeks after transplantation has been associated with fewer incidences of UTIs compared to the removal of UTIs beyond two weeks. 


\section{Cureus}

\begin{tabular}{|c|c|c|c|c|c|}
\hline Author/date & $\begin{array}{l}\text { Study } \\
\text { design }\end{array}$ & Population & $\begin{array}{l}\text { Sample } \\
\text { size }\end{array}$ & Main points & $\begin{array}{l}\text { P- } \\
\text { value }\end{array}$ \\
\hline Patel et al. [7] & $\begin{array}{l}\text { Randomized } \\
\text { controlled } \\
\text { trial }\end{array}$ & $\begin{array}{l}\text { Patients aged 2-75 years undergoing renal } \\
\text { transplantation in the six UK hospitals. }\end{array}$ & 205 & $\begin{array}{l}\text { After renal transplantation, late } \\
\text { removal of the stent at week } 6 \text { had a } \\
\text { higher incidence of UTI } 31 \text { out of } 126 \\
\text { subjects }(24.6 \%) \text { compared to early } \\
\text { removal at day } 5,6 \text { of } 79(7.6 \%) .\end{array}$ & $\begin{array}{l}P= \\
0.004\end{array}$ \\
\hline $\begin{array}{l}\text { Huang et al. } \\
\text { [8] }\end{array}$ & $\begin{array}{l}\text { Randomized } \\
\text { controlled } \\
\text { trial }\end{array}$ & $\begin{array}{l}\text { Two groups based on the duration of double- } J \text { stent } \\
\text { placement was, group } 1 \text { six weeks and group } 2 \text { three } \\
\text { weeks. Group } 1 \text { included } 186 \text { patients and group } 2 \\
\text { included } 179 \text { patients. }\end{array}$ & 365 & $\begin{array}{l}\text { Compared to group 1, patients in } \\
\text { group } 2 \text { had fewer UTI episodes. }\end{array}$ & $\begin{array}{l}P= \\
N A\end{array}$ \\
\hline $\begin{array}{l}\text { Parapiboon et } \\
\text { al. [9] }\end{array}$ & $\begin{array}{l}\text { Randomized } \\
\text { controlled } \\
\text { trial }\end{array}$ & $\begin{array}{l}\text { Ureteric stent removal eight days ( } 37 \text { patients) or } \\
\text { routine ureteric stent removal } 15 \text { days ( } 37 \text { patients) } \\
\text { after kidney transplantation in Thailand from April } \\
2010 \text { to January } 2011 \text {. }\end{array}$ & 74 & $\begin{array}{l}\text { removal was less than the routine stent } \\
\text { removal group }(15 / 37,40.5 \% \text { vs } 27 / 37 \text {, } \\
72.9 \% \text { ) }\end{array}$ & $\begin{array}{l}P= \\
0.004\end{array}$ \\
\hline $\begin{array}{l}\text { Tavakoli et al. } \\
\text { [10] }\end{array}$ & $\begin{array}{l}\text { Randomized } \\
\text { controlled } \\
\text { trial }\end{array}$ & $\begin{array}{l}\text { Patients receiving a renal transplant were randomized } \\
\text { preoperatively to undergo double-J stent (112) or no- } \\
\text { stent (89) ureterovesical anastomosis from November } \\
1998 \text { to October } 2001 .\end{array}$ & 201 & $\begin{array}{l}\text { Higher incidence of UTI in patients with } \\
\text { stent in situ for }>30 \text { days after } \\
\text { transplantation compared to the rate in } \\
\text { those with no stent. }\end{array}$ & $\begin{array}{l}P< \\
0.02\end{array}$ \\
\hline Liu et al. [11] & $\begin{array}{l}\text { Prospective, } \\
\text { randomized } \\
\text { clinical trial }\end{array}$ & $\begin{array}{l}\text { Between October } 2010 \text { and March } 2015 \text { patients with } \\
\text { early ureteral stent removal at week } 1 \text { (52) for group } 1 \\
\text { or the routine ureteral stent removal at week } 4 \text { (51) for } \\
\text { group } 2 \text { in KTR. }\end{array}$ & 103 & $\begin{array}{l}\text { Three episodes of UTls occurred in the } \\
\text { 1-week stent group, and } 18 \text { such } \\
\text { episodes were recorded in the } 4 \text {-week } \\
\text { stent group } 5.8 \% \text { vs } 29.4 \%\end{array}$ & $\begin{array}{l}P= \\
0.002\end{array}$ \\
\hline $\begin{array}{l}\text { Luján et al. } \\
\text { [12] }\end{array}$ & $\begin{array}{l}\text { Controlled } \\
\text { clinical trial }\end{array}$ & $\begin{array}{l}111 \text { patients with double } \mathrm{J} \text { catheter and another of } 83 \\
\text { catheter-free patients. }\end{array}$ & 194 & $\begin{array}{l}\text { No differences between the two } \\
\text { groups in regards to UTI } 3(2.7 \%) \text { in the } \\
\text { catheter group and } 1(1.2 \%) \text { in the } \\
\text { catheter-free group. }\end{array}$ & $\begin{array}{l}P= \\
0.63\end{array}$ \\
\hline $\begin{array}{l}\text { Menezes et } \\
\text { al. [5] }\end{array}$ & $\begin{array}{l}\text { Randomized } \\
\text { controlled } \\
\text { trial }\end{array}$ & $\begin{array}{l}\text { From March } 2013 \text { to December } 2014 \text {, a randomized } \\
1: 1 \text { ratio through computer-generated system to a } \\
\text { nitrofurazone-coated silicone urinary catheter and } \\
\text { non-impregnated silicone urinary catheter in São } \\
\text { Paulo, Brazil. }\end{array}$ & 176 & $\begin{array}{l}\text { No differences noted in the rates of UTI } \\
(8 \% \text { in the nitrofurazone group and } \\
6.8 \% \text { in the control group. }\end{array}$ & $\begin{array}{l}P= \\
0.99\end{array}$ \\
\hline
\end{tabular}

TABLE 3: Summary of studies showing the effect of early removal of the ureteric stent/catheters earlier in reducing the incidence of UTI in the KTR

UTI: urinary tract infection, KTR: kidney transplant recipient.

The role of antimicrobials in the control of the incidence rate of UTI in the KTR has also been discussed in these papers. The published studies have shown that the perioperative and postoperative use of antibiotics has beneficial effects on individuals undergoing renal transplantation. Table 4 demonstrates the impacts of antimicrobial use on the occurrence of UTI in KTR. In summary, individuals undergoing kidney transplants treated with antibiotics in the perioperative and postoperative periods had a lower incidence of UTI relative to those individuals who did not receive any antimicrobials; however, the choice of antimicrobials differs. 


\section{Cureus}

\begin{tabular}{|c|c|c|c|c|c|}
\hline Author/date & $\begin{array}{l}\text { Study } \\
\text { design }\end{array}$ & Population & $\begin{array}{l}\text { Sample } \\
\text { size }\end{array}$ & Main points & $\begin{array}{l}\text { P- } \\
\text { value }\end{array}$ \\
\hline $\begin{array}{l}\text { Lee et al. } \\
\text { [13] }\end{array}$ & Clinical trial & $\begin{array}{l}\text { Adult KTR between September } 2014 \text { and December } \\
2015 .\end{array}$ & 277 & $\begin{array}{l}56 \text { recipients }(20 \%) \text { received } \\
\text { additional antibiotic prophylaxis } \\
(A B X+) \text { and } 221(80 \%) \text { did not (ABX-) } \\
\text { at the time of ureteral stent removal. } \\
\text { The difference in the occurrence of } \\
\text { UTI in the } A B X(+) \text { group }(16 \%) \text { and } \\
A B X(-) \text { group }(19 \%) \text { was insignificant. }\end{array}$ & $\begin{array}{l}P= \\
0.85\end{array}$ \\
\hline $\begin{array}{l}\text { Arreola- } \\
\text { Guerra et al. } \\
{[4]}\end{array}$ & $\begin{array}{l}\text { Randomized } \\
\text { controlled } \\
\text { trial }\end{array}$ & $\begin{array}{l}\text { The intervention group including } 32 \text { patients who } \\
\text { received } 3 \mathrm{~g} \text { of FOS PO every } 10 \text { days and TMP-SMX } \\
\text { (160/800 } \mathrm{mg} \text { ) three times per week (group } 1 \text { ), whereas } \\
\text { the control group including } 35 \text { patients who received } \\
\text { TMP-SMX ( } 160 / 800 \mathrm{mg} \text { ) daily (group } 2 \text { ). }\end{array}$ & 67 & $\begin{array}{l}\text { The incidence of UTI in group } 1 \text { vs } \\
\text { group } 2 \text { was } 40.6 \% \text { vs } 42.8 \% \text {. }\end{array}$ & $\begin{array}{l}P= \\
0.85\end{array}$ \\
\hline $\begin{array}{l}\text { Salehipour } \\
\text { et al. [14] }\end{array}$ & $\begin{array}{l}\text { Randomized } \\
\text { controlled } \\
\text { trial }\end{array}$ & $\begin{array}{l}\text { The bladders of the group 1, the amikacin group, were } \\
\text { filled with a saline solution containing amikacin ( } 1 \mathrm{~g} \text { in } \\
\text { adults and } 30 \mathrm{mg} / \mathrm{kg} \text { in pediatric patients), whereas the } \\
\text { bladders of the patients of the group } 2 \text {, the control } \\
\text { group, were filled with a saline solution and were } \\
\text { followed up for three months after transplantation. }\end{array}$ & 200 & $\begin{array}{l}\text { The overall incidence of UTIs was } \\
\text { found to be significantly lower in the } \\
\text { amikacin group ( } 25 \text { vs. } 49 \% \text { ). }\end{array}$ & $\begin{array}{l}P= \\
0.0007\end{array}$ \\
\hline $\begin{array}{l}\text { Hibberd et } \\
\text { al. [15] }\end{array}$ & $\begin{array}{l}\text { A double- } \\
\text { blind, } \\
\text { randomized } \\
\text { controlled } \\
\text { trial }\end{array}$ & $\begin{array}{l}\text { To compare low-dose TMP/SXT with ciprofloxacin for } \\
\text { the prevention of UTI in KTR. Patients received either } \\
\text { ciprofloxacin ( } 250 \mathrm{mg} \text { ), } 51 \text { patients or TMP/SXT ( } 80 \mathrm{mg} \\
\text { trimethoprim, } 400 \mathrm{mg} \text { sulfamethoxazole) } 52 \text { patients } \\
\text { daily for six months following transplantation. }\end{array}$ & 103 & $\begin{array}{l}\text { Treatment was successful in } 75 \% \text { ( } 38 \\
\text { of } 51 \text { ) receiving ciprofloxacin and } \\
71 \% \text { ( } 37 \text { of } 52 \text { ) treated with TMP/SXT. } \\
\text { Ciprofloxacin is at least as effective } \\
\text { as TMP/SXT. }\end{array}$ & $\begin{array}{l}P= \\
0.87\end{array}$ \\
\hline $\begin{array}{l}\text { Khosroshahi } \\
\text { et al. [16] }\end{array}$ & $\begin{array}{l}\text { Randomized } \\
\text { controlled } \\
\text { trial }\end{array}$ & $\begin{array}{l}\text { The efficacy of various doses of TMP/SXT was } \\
\text { observed in group } 1(n=63) \text { who received low to } \\
\text { moderate doses of TMP/SXT (either } 80 / 400 \mathrm{mg} \text { or } \\
160 / 800 \mathrm{mg} \text {, daily) and group } 2(\mathrm{n}=32) \text { who received } \\
\text { high doses of TMP/SXT }(320 / 1600 \mathrm{mg}) \text {, daily in two } \\
\text { divided doses. }\end{array}$ & 95 & $\begin{array}{l}\text { UTI was observed in about } 25 \% \text { of } \\
\text { patients on the high-dose versus } \\
49.2 \% \text { of those on low- to moderate- } \\
\text { dose prophylaxis. }\end{array}$ & $\begin{array}{l}P< \\
0.05\end{array}$ \\
\hline
\end{tabular}

TABLE 4: Impact of antimicrobials use over the incidence of UTI in KTR

KTR: kidney transplant recipient, UTI: urinary tract infection, TMP/SXT: trimethoprim-sulfamethoxazole, FOS: fosfomycin trometamol.

The data have also been analyzed in various ways to deal with the asymptomatic UTI in the KTR. The studied papers found that the treatment of asymptomatic urinary tract infection in post-transplant individuals has not been shown to be beneficial in preventing symptomatic UTI at a later point. Table 5 summarizes the incidence studies on how to deal with asymptomatic UTI in individuals with kidney transplants. 


\section{Cureus}

\begin{tabular}{|c|c|c|c|c|c|}
\hline Author/date & $\begin{array}{l}\text { Study } \\
\text { design }\end{array}$ & Population & $\begin{array}{l}\text { Sample } \\
\text { size }\end{array}$ & Main points & $\begin{array}{l}\text { P- } \\
\text { value }\end{array}$ \\
\hline $\begin{array}{l}\text { Origuen et al. } \\
\text { [17] }\end{array}$ & $\begin{array}{l}\text { Randomized } \\
\text { controlled } \\
\text { trial }\end{array}$ & $\begin{array}{l}\text { Between January } 2011 \text { and December } 2013 \text {, patients } \\
\text { developing one or more episodes of } A B \text { beyond the second } \\
\text { after transplantation were included in this open-label trial. } \\
\text { Participants were randomized ( } 1: 1 \text { ratio) to the treatment } \\
\text { group (systematic antimicrobial therapy for all episodes of } \\
A B \text { occurring } \leq 24 \text { months after transplantation [ } 53 \text { patients]) } \\
\text { or control group (no antimicrobial therapy [ } 59 \text { patients]). }\end{array}$ & 112 & $\begin{array}{l}\text { No significant differences } \\
\text { noted in the incidence of UTI }\end{array}$ & $\begin{array}{l}P= \\
1.00\end{array}$ \\
\hline $\begin{array}{l}\text { Julien } \\
\text { Coussement et } \\
\text { al. [18] }\end{array}$ & $\begin{array}{l}\text { Cross- } \\
\text { sectional } \\
\text { study }\end{array}$ & $\begin{array}{l}\text { KTR undergoing routine surveillance in three outpatient } \\
\text { transplant clinics in Belgium and France. Patients who were } \\
\text { in the first two months post-transplantation and/or had a } \\
\text { urinary catheter excluded. Asymptomatic participants who } \\
\text { had a urine culture with one organism isolated at } \geq 105 \\
\mathrm{CFU} / \mathrm{mL} \text { were asked to provide a confirmatory urine } \\
\text { specimen. }\end{array}$ & 500 & $\begin{array}{l}\text { Overall, the prevalence of AB } \\
\text { was } 3.4 \%(17 / 500 \text { patients). It } \\
\text { was similarly low among KTR } \\
\text { who were between } 2 \text { and } 12 \\
\text { months after transplantation } \\
(1.3 \%, 1 / 76 \text { patients) and those } \\
\text { who were farther after } \\
\text { transplantation ( } 3.8 \%, 16 / 424 \\
\text { patients: } P=0.49) \text {. }\end{array}$ & $\begin{array}{l}P= \\
0.49\end{array}$ \\
\hline
\end{tabular}

TABLE 5: Summarizes the studies showing the incidence and how to deal with asymptomatic UTI

KTR: kidney transplant recipient, UTI: urinary tract infection, AB: asymptomatic bacteriuria.

The outcome of the study was removing stent earlier after the transplantation which reduces the incidences of getting UTI in KTR patients. Studies have shown that removing these devices one to two weeks after the transplantation has fewer chances of UTI in these individuals as compared to removing it beyond the two weeks period. Similarly, the use of prophylactic antibiotics in the perioperative and postoperative phases has beneficial effects in reducing the occurrence of UTI in these patients. However, the treatment of asymptomatic UTI may not have any beneficial effects to avoid the occurrence of symptomatic UTI at a later stage. More work is needed to find out why the treatment of asymptomatic UTIs has not been associated with any positive outcome in the KTR. There are some limitations to the current literature review: not including papers published other than English, meta-analysis results, animal studies, and many other unexplored variables that can be tested in future studies. The outcome could be different if the limitations have been included.

\section{Conclusions}

In the analysis of 57 published articles, we found out that the early removal of the devices including the ureteric stents and catheters in the post-kidney transplant period and the perioperative and postoperative antimicrobials therapies have been proven beneficial in reducing the chances of getting UTI in KTR. However, this study also found out that treating asymptomatic UTI in KTR has no positive impact in reducing the incidence of symptomatic UTI in KTR later on. More research is needed with a larger cohort and prospective randomized control trials with drugs and placebo to get the answer to this research question that why treating asymptomatic UTI in KTR with the antimicrobials has no benefits.

\section{Additional Information \\ Disclosures}

Conflicts of interest: In compliance with the ICMJE uniform disclosure form, all authors declare the following: Payment/services info: All authors have declared that no financial support was received from any organization for the submitted work. Financial relationships: All authors have declared that they have no financial relationships at present or within the previous three years with any organizations that might have an interest in the submitted work. Other relationships: All authors have declared that there are no other relationships or activities that could appear to have influenced the submitted work.

\section{References}

1. Chen Y-X, Li R, Gu L, Xu K-Y, Liu Y-Z, Zhang R-W: Risk factors and etiology of repeat infection in kidney transplant recipients. Medicine. 2019, 98:e17312. 10.1097/MD.0000000000017312

2. Mukherjee D, Sharma S, Nair RK, Datt B, Arora D, Rao A: Urinary tract infection in renal transplant recipients at a tertiary care center in India. Saudi J Kidney Dis Transpl. 2018, 29:361-368. 10.4103/13192442.229294

3. Coussement J, Scemla A, Abramowicz D, Nagler EV, Webster AC: Antibiotics for asymptomatic bacteriuria 
in kidney transplant recipients. Cochrane Database Syst Rev. 2018, 2:011357.

10.1002/14651858.CD011357.pub2

4. Arreola-Guerra JM, Rosado-Canto R, Alberú J, et al.: Fosfomycin trometamol in the prophylaxis of postkidney transplant urinary tract infection: a controlled, randomized clinical trial. Transpl Infect Dis. 2018, 20:e12980. 10.1111/tid.12980

5. Menezes FG, Corrêa L, Medina-Pestana JO, Aguiar WF, Camargo LF: A randomized clinical trial comparing nitrofurazone-coated and uncoated urinary catheters in kidney transplant recipients: results from a pilot study. Transpl Infect Dis. 2019, 21:e13031. 10.1111/tid.13031

6. Gokulnath RS: Intractable urinary tract infection in a renal transplant recipient . Saudi J K Dis Transpl. 2009, 20:458-461.

7. Patel P, Rebollo-Mesa I, Ryan E, et al.: Prophylactic ureteric stents in renal transplant recipients: a multicenter randomized controlled trial of early versus late removal. Am J Transplant. 2017, 17:2129-2138. 10.1111/ajt.14223

8. Huang L, Wang X, Ma Y, Wang J, Tao X, Liao L, Tan J: A comparative study of 3-week and 6-week duration of double-J stent placement in renal transplant recipients. Urol Int. 2012, 89:89-92. 10.1159/000338075

9. Parapiboon W, Ingsathit A, Disthabanchong S, et al.: Impact of early ureteric stent removal and cost-benefit analysis in kidney transplant recipients: results of a randomized controlled study. Transplant Proc. 2012, 44:737-739. 10.1016/j.transproceed.2011.11.033

10. Tavakoli A, Surange RS, Pearson RC, Parrott NR, Augustine T, Riad HN: Impact of stents on urological complications and health care expenditure in renal transplant recipients: results of a prospective, randomized clinical trial. J Urol. 2007, 177:2260-2264. 10.1016/j.juro.2007.01.152

11. Liu S, Luo G, Sun B, et al.: Early removal of double-J stents decreases urinary tract infections in living donor renal transplantation: a prospective, randomized clinical trial. Transplant Proc. 2017, 49:297-302. 10.1016/j.transproceed.2016.12.007

12. Luján S, García-Fadrique G, Budía A, Broseta E, Jiménez-Cruz F: [Should ureteral catheterization be systematically used in kidney transplants?]. Actas Urol Esp. 2011, 35:213-217. 10.1016/j.acuro.2010.10.009

13. Lee JH, Muthukumar T, Kim J, Aull MJ, Watkins A, Kapur S, Hartono C: Antibiotic prophylaxis for ureteral stent removal after kidney transplantation. Clin Transplant. 2019, 33:e13491. 10.1111/ctr.13491

14. Salehipour M, Salahi H, Fathikalajahi A, et al.: Is perioperative intravesically applied antibiotic solution effective in the prophylaxis of urinary tract infections after renal transplantation?. Urol Int. 2010, 85:66-69. $10.1159 / 000296303$

15. Hibberd PL, Tolkoff-Rubin NE, Doran M, et al.: Trimethoprim-sulfamethoxazole compared with ciprofloxacin for the prevention of urinary tract infection in renal transplant recipients: a double-blind, randomized controlled trial. Online J Curr Clin Trials. 1992, 1:15.

16. Khosroshahi HT, Mogaddam AN, Shoja MM: Efficacy of high-dose trimethoprim-sulfamethoxazol prophylaxis on early urinary tract infection after renal transplantation. Transplant Proc. 2006, 38:20622064. 10.1016/j.transproceed.2006.06.111

17. Origüen J, López-Medrano F, Fernández-Ruiz M, et al.: Should asymptomatic bacteriuria be systematically treated in kidney transplant recipients? Results from a randomized controlled trial. Am J Transplant. 2016, 16:2943-2953. 10.1111/ajt.13829

18. Coussement J, Scemla A, Hougardy J-M, Sberro-Soussan R, Amrouche L: Prevalence of asymptomatic bacteriuria among kidney transplant recipients beyond two months post-transplant: a multicenter, prospective, cross-sectional study. PloS One. 2019, 14:e0221820. 10.1371/journal.pone.0221820 